\title{
Slik ble multer brukt mot skjørbuk
}

\section{Skjørbuk var tidligere en vanlig og mye fryktet sykdom. To viktige skandinaviske historiske kilder fra 1593 og 1635 er nå oversatt fra latin til engelsk.}

En av de første utdannede leger som kom til Norge, var tyskeren Henrik Høyer. Han startet sin praksis i Bergen 1593. Han fikk vite av nordlendinger som kom til Bergen med tørrfisk, at skjørbuk kunne helbredes med multer. Høyer skrev et lengre brev om dette til botanikere i Leyden og besøkte noen år senere en professor i botanikk i Leyden, Carolus Clusius. Høyer hadde da med seg både multer og multeplanter, som ble beskrevet i Clusius' omfattende plantebok fra 1601. En annen

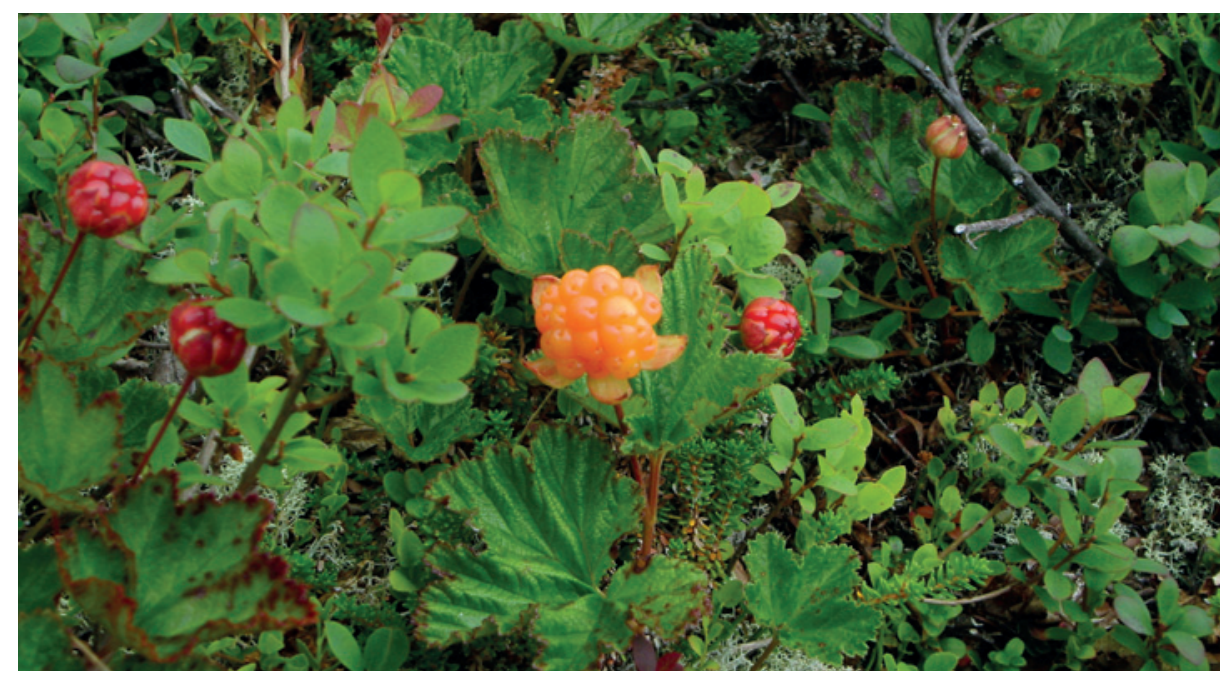

Multer i Finnmark. Bildet er brukt som forsideillustrasjon i Journal of Nutrition. Foto Kaare R. Norum tysker, Ambrosius Rhodius, skrev den første skandinaviske doktoravhandling om skjørbuk, og forsvarte i 1635 sin avhandling ved Universitetet i København.

Brevet fra Høyer og avhandlingen fra Rhodius var begge skrevet på latin. Vi har nylig oversatt disse tekstene til engelsk (1). Tekstene gir et godt inntrykk av hvordan skjørbuk ble oppfattet på den tiden. Høyers brev er vesentlig en beskrivelse av hvordan multer på kort tid kan helbrede skjørbuk,

mens Rhodius i sin doktoravhandling omtaler de kliniske tegn og symptomer og diskuterer hva som kan forårsake sykdommen. Han er inne på en rekke årsaksfaktorer, diskuterer behandlingen av sykdommen, fremhever at en del planter kan brukes og refererer til Høyers beskrivelse av multenes helbredende virkning. Det at enkelte planter kunne forebygge og helbrede skjørbuk, førte til at kong Christian IV forlangte en total oversikt over hvilke planter som vokste i hans kongerike. Dette ble den forste Flora Danica, som utkom i tre bind 1646-49. Her er Høyer sitert og multenes helbredende virkning nevnt.

I artikkelen diskuterer vi arbeidene til Høyer og Rhodius og gir en oversikt over oppfatningen av skjørbuk gjennom tidene. Vikingene visste at multer forhindret skjørbuk, og James Lind skjønte at sitrusfrukter kunne forebygge skjørbuk. Men både multer og sitrusfrukters betydning ble glemt, og på slutten av 1800-tallet ble skjørbuk betraktet som en forgiftning av bedervet mat. Fridtjof Nansen trodde på den teorien, men det var en rikelig beholdning av multer om bord som forhindret at mannskapet på «Fram» fikk skjørbuk!

\section{Kaare R. Norum}

krnorum@gmail.com

Avdeling for ernæringsvitenskap

Universitetet i Oslo

\section{Litteratur}

1. Luca LMD, Norum KR. Scurvy and cloudberries: a chapter in the history of nutritional sciences. J Nutr 2011; 141: 2101-5.

\section{Glutenintoleranse uten cøliaki}

\section{Er glutenoverfølsomhet involvert i patogenesen ved irritabel tarm- syndrom?}

Mange personer med irritabel tarm-syndrom forteller at de er bedre når de holder seg til glutenfri kost. En ny studie fra Australia tyder på at det kan være en sammenheng (1).

Studien omfattet 34 pasienter med irritabel tarm-syndrom og selvrapportert glutenoverfølsomhet. Cøliaki ble utelukket ved negativ genotypetesting for HLA-DQ8/-DQ2 og/eller normale duodenalbiopsier. Alle pasientene fulgte glutenfri diett og hadde oppnådd god symptomkontroll. De ble randomisert til å spise en muffins og to brødskiver med eller uten gluten ekstra hver dag i seks uker.
Gruppen som fikk gluten, opplevde klart dårligere symptomkontroll enn placebogruppen $(p=0,001)$. Pasientene i glutengruppen var gjennomgående mer plaget av smerte, oppblåsthet, avføringsproblemer og tretthet, mens graden av flatulens og kvalme var lik. Det ble ikke påvist forskjeller i målte biomarkører, slik som antistoffer mot endomysium, vevstransglutaminase og gliadin, høysensitivt CRP, intestinal permeabilitet og fekalt laktoferrin, mellom de to gruppene.

- Det er for tiden stor internasjonal interesse for glutenintoleranse uten cøliaki, som på engelsk gjerne kalles «non-celiac gluten sensitivity», sier overlege Knut E.A. Lundin ved Seksjon for gastromedisin, Oslo universitetssykehus. Enkelte data tyder på at tilstanden rammer 5-6\% av befolkningen. Salget av glutenfrie matvarer øker sterkt og langt mer enn veksten av antallet cøliakere tilsier, sier han.

- Studien er den første randomiserte, dobbeltblindede placebokontrollerte undersøkelsen innen feltet og er derfor et verdifullt bidrag. Med økende evidens for at glutenintoleranse uten cøliaki faktisk eksisterer, kan vi konsentrere oss om den spennende jakten på mekanismene bak tilstanden, sier Lundin.

\section{Jørgen Valeur}

jorgen.valeur@med.uib.no

Lovisenberg Diakonale Sykehus

\section{Litteratur}

1. Biesiekierski JR, Newnham ED, Irving PM et al. Gluten causes gastrointestinal symptoms in subjects without celiac disease: a double-blind randomized placebo-controlled trial. Am J Gastroenterol 2011; 106: 508-14. 